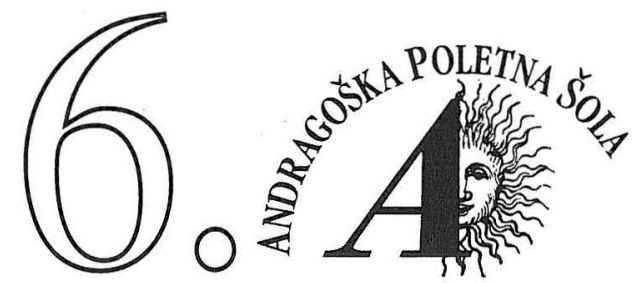

\title{
IZOBRAŽEVALNO SVETOVANJE IN UČNI PROJEKTI ODRASLIH - TEMELJ REGIONALNEGA RAZVOJA
}

etošnja Andragoška poletna šola je potekala od 5. do 9. junija 2000 v Ajdovščini, mestecu, kjer se pije kavo v stolpu rimskega obzidja in kjer pozimi piha tako močna burja, da je po legendi pomagala pri razpletu bitke pri Frigidusu in tako bistveno vplivala na evropsko zgodovino. V Andragoški poletni šoli niso imele vidnejše vloge legende in zgodovina, marveč se je razpravljalo o učenju posameznika, o tistem učenju, ki je bistveno za njegov razvoj in razvoj skupnosti $v$ današnjem času. Na razvoju skupnosti pa temelji regionalni razvoj.

Poletne šole se je udeležilo nekaj nad trideset izobraževalk in izobraževalcev odraslih. Že uvodna predstavitev ciljev izobraževanja je pokazala na centralizacijo izobraževalne ponudbe $\mathrm{v}$ Ljubljani in drugih večjih središčih ter nakazala vprašanje, kako ponuditi izobra-

»Praviš, da si bil tam in dolgo čakal, preden te je učitelj sprejel. Poslušal si ga, a ga nisi razumel. Najbolîsi učitelj ne uči svojih učencev, ker jih spoštuje. Osvobaja jih, da zagledajo pot do sebe, do edinega učitelja, ki jih lahko uči. « (Rudi Kerševan) ževanje tudi na podeželju. V celotedenskem druženju so ugotavljali, kako širiti in povezovati učne projekte ter druge vzorce učenja. Pri razvoju individualnega učenja ima pomembno vlogo andragoško svetovanje.

Izobraževanje odraslih izhaja iz človekovih potreb. Množično izobraževanje za odrasle ne zadošča, dopolniti ga je treba $\mathrm{z}$ individualnimi oblikami v različnih učnih okoljih.

$\mathrm{V}$ poletni šoli se udeleženci učijo drug od drugega. Vsako leto si izmenjajo izkušnje, nekatere $v$ neformalnih klepetih, druge med razpravljanjem po predavanjih. Letos smo pripravili tudi »exchange session«, sejem idej, ki je bil pravi ognjemet izkušenj, vrednih posnemanja. Ves večer so prodajali in kupovali ideje, na koncu so »sejmarje« iz osrednjega prostora Lavričeve knjižnice zvabile dobrote, ki so jih pripravile ženske z Gore, planote nad Ajdovščino, ki se družijo v študijskem krožku v domači vasi. Pripravile so pojedino z lokalnimi jedmi, začenši s kislim mlekom in domačim kruhom, več vrstami kuhanih štrukljev ... Mimogrede naj članicam študijskega krožka podeželskih žena s Predmeje še čestitamo za priznanje Andrago- 


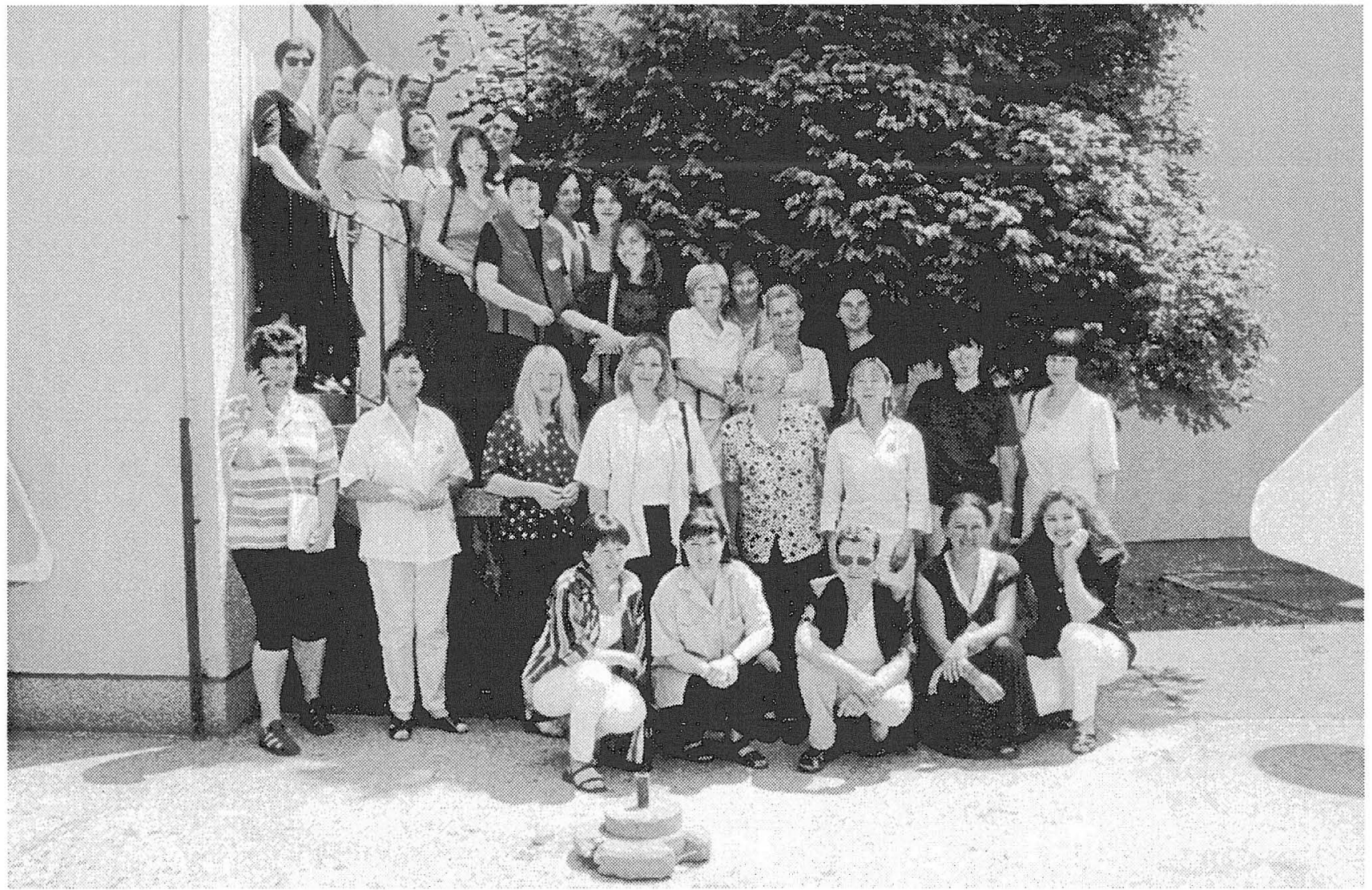

škega centra Slovenije za posebne dosežke pri bogatitvi njihovega znanja. Večerne prireditve, ki jih organizirata poletna šola in Lavričeva knjižnica, so namenjene druženju udeležencev APŠ in domačinov. Letos sta se poleg že omenjenih članic študijskega krožka predstavila še Mirko Kovač in Iris Suban. Mirko Kovač, meteorolog, doma iz Lokavca, je z diapozitivi opremil pripoved o svoji knjigi o vremenu med Čavnom in Nanosom. V torek zvečer pa so se besede stkale ob pesmih Iris Suban. Zadnji večer so se »šolarji« odpravili na ekskurzijo. Povzpeli so se do obnovljene cerkvice sv. Martina nad Brjami. Svetišče je na vrhu Vipavskih Brd, ki jih ne kaže zamenjevati z Goriškimi Brdi. Od tod je lep razgled po Vipavski dolini, ki se širi v Goriško ravan. Na Brjah je bila leta 1903 na pobudo tamkajšnjega učitelja Antona Možine ustanovljena Zveza bralnih in pevskih društev na Vipavskem. Gabršček (1934) navaja del njegovega govora, $v$ katerem je poudaril, da je čas, »da se društva povzpno više, kar naj izvrši zveza. Ob enotnem vodstvu vseh kulturnih društev tega okolja bi odpadla kvarna tekma med društvi.« Možina je o tem govoril že davnega leta 1903. Še danes velja kot eno temeljnih načel skupnostnega razvoja, naj tekmovanje zamenja sodelovanje. Za razvoj so pomembni vsi ljudje in skupine v okolju.

In kaj so počeli udeleženci dopoldne in popoldne? Tudi $v$ tem času je vladalo sproščeno razpoloženje, brez formalne zapetosti, z veliko vprašanj in komentarjev. $\mathrm{K}$ temu je pripomogla letošnja gostja, profesorica $\mathrm{z}$ univerze v Glasgowu, Maria Slowey, ugledna predavateljica in urednica revije Scottish Journal of Adult and Continuing Education. 


\section{LOKALNI RAZVOI TEMELII NA LOKALNI SKUIPNOSTI, LJUDEH, NJIHOVIH POVEZAVAH, SODELOVANJU, USTVARJALNOSTI, POBUDAH}

Moderatorke učenja v dopoldanskem delu so svoje prispevke in razmišljanje udeležencev krmarile $\mathrm{v}$ iskanje povezav med učenjem in lokalnim razvojem. Sledila so predavanja in razprave. Maria Slowey je predstavila učne projekte odraslih v lokalni skupnosti. Ana Krajnc je spregovorila o tem, kako pripraviti individualni izobraževalni načrt, Nadja Dobnik pa o vsebinskih virih za osebni izobraževalni načrt. Tanja Vilič Klenovšek je v svojem predavanju Razvoj informativne dejavnosti v lokalni skupnosti osvetlila značilnosti svetovanja, po katerih se ta dejavnost razlikuje od navadnega informiranja. Nena Mijoč je govorila o izobraževanju odraslih $\mathrm{z}$ delovanjem, s Sabino Jelenc Krašovec pa so se »poletni šolarji« učili o učeči se organizaciji. In ker je tudi družina ena od tistih skupin, v kateri se odrasli učijo, je Nives Ličen predavala o učenju odraslih, povezanem $\mathrm{z}$ družino.

$\mathrm{V}$ popoldanskem času so udeleženci $\mathrm{v}$ dveh skupinah, ki sta ju vodili Monika Govekar Okoliš in Nena Mijoč, razpravljali o izobraževalnih biografijah, individualnih izobraževalnih načrtih ter svetovanju. Zelo zanimivo je bilo terensko delo, pri katerem so skušali v pogovorih $\mathrm{z}$ domačini zbrati najpogostejše oblike tako imenovanega spontanega učenja na podeželju, zanimalo jih je, kje in kako se ljudje na podeželju učijo. Želeli so spoznati vzorce učenja, prenašanja in graditve znanja, navad, veščin, da bi na teh temeljih zrasla ponudba novih modelov nadaljnjega izobraževanja. Zadnji dan je bil namenjen kritični presoji učenja in ugotovitev. Sonja Kump je pripravila predavanje o evalvaciji študijskih projektov. Poudarila je, da je cilj evalvacije izpopolnjevanje kakovosti in da se moramo še naučiti »kulture evalvacije«. Predstavila je izho-

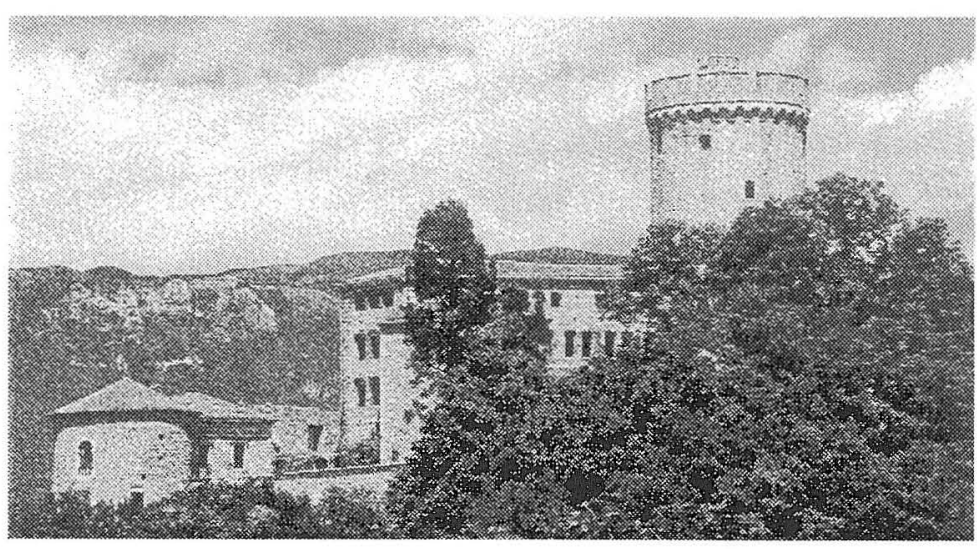

diščne točke za samoevalvacijo, ki so jih uporabili za evalvacijo Andragoške poletne šole. Temu je sledilo poročanje o delu skupin na terenu in predlogih, ki so se porodili v pogovorih s prebivalci vasi okrog Ajdovščine. Če na grobo povzamemo, se je izkazalo, da je treba graditi mrežo med učečimi se posamezniki in skupinami. Predlagali so, da bi odprli svetovalno središče, ki bi ljudem omogočalo različne informacije in svetovanje.

Ljudje veliko vedo, mnogo so se sami naučili pri vsakdanjem delu. Izobraževanje naj bi to povezalo, razvilo strategije, s katerimi bodo ljudje premagali strahove in molčečnost, se upali zavzeti zase in za svoj kraj. Zdi se, da Andragoška poletna šola združuje $v$ podiplomskem izobraževanju andragogov dve poti, ki ju skuša uveljaviti tudi pri nas. Ena pot izhaja iz Freirove metode dialoga in njegove oblike »kulturnih krožkov«, druga pa kaže na izhodišča v skupnostnem izobraževanju, razširjenem v zahodnoevropskih državah. S tem in z izkušnjami udeležencev razvija Andragoška poletna šola nove pristope.

Nives Ličen 